\title{
An evaluation of the effectiveness of a chemical additive based on sodium benzoate, potassium sorbate, and sodium nitrite on the fermentation and aerobic stability of corn silage
}

\author{
Limin Kung Jr., ${ }^{* 1}$ Megan L. Smith, ${ }^{*}$ Erica Benjamim da Silva, ${ }^{*}$ Michelle C. Windle, ${ }^{*}$ Thiago C. da Silva, $\dagger^{2}$ \\ and Stephanie A. Polukis* \\ *Department of Animal and Food Sciences, University of Delaware, Newark 19716 \\ †Federal University of Vicosa, Vicosa, Minas Gerais, Brazil 36570000
}

\section{ABSTRACT}

We evaluated the effectiveness of an additive comprising sodium benzoate, potassium sorbate, and sodium nitrite (SSL) as active ingredients for its ability to improve the aerobic stability of corn silages made in North America. In experiment 1, treatment with SSL $(1.5$ and $2.0 \mathrm{~L} / \mathrm{t})$ on whole-plant corn $(\mathrm{WPC})$ was compared with treatment with an additive containing buffered propionic acid and citric acid (BPA; $2 \mathrm{~L} / \mathrm{t}$ ) on corn harvested at 32 and $38 \%$ dry matter and ensiled for $120 \mathrm{~d}$. Silage treated with BPA was higher in ammonia-N and propionic acid relative to other treatments. Treatments with all of the additives had numerically, but not statistically, fewer yeasts compared with untreated silage. Both application rates of SSL resulted in lower concentrations of ethanol compared with untreated and BPA silages. Treatment with BPA improved the aerobic stability of silages compared with untreated silage, but the effect from SSL was markedly greater. In experiment 2 , WPC was untreated or treated with 2 or $3 \mathrm{~L}$ of SSL/t or a microbial inoculant containing Enterococcus faecium M74, Lactobacillus plantarum CH6072, and Lactobacillus buchneri LN1819 (final total lactic acid bacteria application rate of $150,000 \mathrm{cfu} / \mathrm{g}$ of fresh forage). Silages were air stressed for $24 \mathrm{~h}$ at 28 and $42 \mathrm{~d}$ of storage and ensiled for $49 \mathrm{~d}$ before opening. Inoculation had no effect on acid end products, ethanol, number of yeasts, or aerobic stability compared with other treatments. Treatment with SSL decreased the amount of ethanol, had no effect on number of yeasts, and improved aerobic stability in a dose-dependent manner compared with other treatments. In experiment 3, WPC was untreated or treated

\footnotetext{
Received October 17, 2017.

Accepted February 26, 2018.

${ }^{1}$ Corresponding author: lksilage@udel.edu

${ }^{2}$ Current address: Animal Science Department, Federal University of Goias, Goiânia, Goias, Brazil 74690900.
}

with $2 \mathrm{~L}$ of SSL/t and ensiled for 5,15 , and $30 \mathrm{~d}$. Treatment with SSL resulted in silage with fewer yeasts and lower concentrations of ethanol after all times of ensiling compared with untreated silage. In addition, SSL improved aerobic stability after each period of ensiling, but the effect was more at 15 and $30 \mathrm{~d}$ compared with 5 d of storage. Treating WPC with SSL can improve the aerobic stability of corn silage made in North America, and the effect can be observed as soon as $5 \mathrm{~d}$ after ensiling.

Key words: aerobic stability, antifungal, silage

\section{INTRODUCTION}

Corn silage is the most common type of silage fed to dairy cows in North America, but it can spoil rapidly when exposed to air during storage or feedout, especially in warm weather. Yeasts that metabolize lactic acid under aerobic conditions are usually the initiators of this process (Woolford, 1990), resulting in an oxidation of nutrients characterized by heating of the silage mass. Feeding spoiled silage is undesirable because it is lower in nutritive value than fresh silage and it can depress DMI (Hoffman and Ocker, 1997; Windle and Kung, 2013). Spoiled silage that is not fed and is discarded results in a loss of valuable feed inventory.

Many factors affect the aerobic stability of silages. For example, air can penetrate into a silage mass during prolonged storage, especially if the packing density is low because air penetrates deeply into porous material (Pitt and Muck, 1993). Air can penetrate into the face of a silo as much as $1 \mathrm{~m}$ (Muck and Huhnke, 1995) even in adequately packed silos. If $20 \mathrm{~cm}$ of silage is removed per day due to feedout, the average silage being fed would have been exposed to air for about 4 to 5 d. Silages that are high in DM $(>40 \%)$ have lower concentrations of natural antifungal compounds (e.g., acetic acid) than wetter silages $(<30 \% \mathrm{DM})$, and thus they are often more prone to aerobic spoilage. Silages that are exposed to air in warm weather will also spoil 
more quickly because most yeasts are mesophilic and grow best between 20 and $30^{\circ} \mathrm{C}$ (Deak, 2008).

Microbial-based additives have been applied to forages at the time of harvest to specifically improve the aerobic stability of silages (Kung et al., 2003). The added microbes must compete with other microorganisms in the silo and produce sufficient amounts of antifungal end products to improve aerobic stability, but this process can take weeks or months. For example, the improvement in aerobic stability obtained via the production of acetic acid by Lactobacillus buchneri requires at least 45 to $60 \mathrm{~d}$ of ensiling (Kleinschmit and Kung, 2006; Schmidt et al., 2009). In many instances, dairy farmers are forced to feed silage from freshly filled silos after very short periods of time of ensiling. In these situations, L. buchneri would not have sufficient time to increase acetic acid and improve aerobic stability. An alternative solution for improving the aerobic stability of silages is through the use of chemical additives whose primary active antifungal ingredients are short-chain organic acids. Although the cost of using chemical additives is relatively more than that of using microbial-based additives, in their favor, the former is not dependent on the growth of microorganisms to produce active end products. Buffered propionic acid is one of the most common antifungal ingredients in many chemical-based silage additives sold in North America. This acid has improved the aerobic stability of cornbased crops (Britt et al., 1975; Kung et al., 2000). More recently, potassium sorbate and sodium benzoate have also been effective in improving the aerobic stability of silages (Knicky and Spörndly, 2011; Nadeau et al., 2012; Seppala et al., 2016), but research with these compounds on corn silage in North America is limited (Kleinschmit et al., 2005; Queiroz et al., 2013; Hafner et al., 2015) and data supporting their efficacy after short periods of ensiling are lacking.

The objective of this study was to evaluate the effects of a chemical additive, developed in Europe, comprising the active ingredients sodium benzoate, potassium sorbate, and sodium nitrite (SSL), on the fermentation and aerobic stability of corn silage. In experiment 1, we compared the effects of SSL with those of an additive containing buffered propionic acid and citric acid on corn silage harvested at 2 concentrations of DM (32 and $38 \%$ ). In experiment 2, SSL was compared with a microbial containing $L$. buchneri LN1819 on the ability to improve the aerobic stability of corn silage that was subjected to air stress during storage. In experiment 3, we determined whether SSL could improve the aerobic stability of corn silage after relatively short periods of ensiling (5, 15, and $30 \mathrm{~d}$ ). Collectively, these were the first group of experiments to evaluate SSL on corn silage in North America.

\section{MATERIALS AND METHODS}

\section{General Information}

The experiments were conducted between 2012 and 2015 at the University of Delaware Farm, Newark. Corn was planted in fields of silt loam soil. Fields had been managed with a corn-alfalfa rotation or continuous corn. Fields were fertilized with manure (sheep, cow, and horse). At planting, a pop-up liquid fertilizer (3-54) was applied at $9.35 \mathrm{~L} / \mathrm{ha}$. Side dressing with $421 \mathrm{~L} /$ ha of $30 \%$ urea-ammonium nitrate occurred between the V5 and V6 stages of maturity. A pre-emergence herbicide, Lumax (Syngenta US, Greensboro, NC), was applied within $3 \mathrm{~d}$ of planting. Corn was planted at a stand population between 73,482 and 77,805 seeds/ha.

\section{Experiment 1}

Whole-plant corn (P1376XR, DuPont Pioneer, Johnston, IA) was harvested at $32 \% \mathrm{DM}$ and chopped to a theoretical length of $19 \mathrm{~mm}$ using a pull-type chopper (3975, John Deere, Moline, IL) equipped with a kernel processor with a roller gap set to $1.4 \mathrm{~mm}$. Several days later, using the same field and variety, additional corn was harvested at $38 \%$ DM with the same equipment. Plants at each harvest were obtained from 5 random locations within the field to correspond with 5 replicates per treatment. Five replicated piles of forage were prepared for each of the following treatments at each concentration of DM: (1) untreated (CON), (2) 1.5 L of $\mathrm{SSL} / \mathrm{t}$ of fresh forage weight (S1.5; Safesil Ab Hanson \& Mohring, Halmstad, Sweden; contained $200 \mathrm{~g} / \mathrm{kg}$ of sodium benzoate, $100 \mathrm{~g} / \mathrm{kg}$ of potassium sorbate, and $50 \mathrm{~g} / \mathrm{kg}$ of sodium nitrite), (3) $2 \mathrm{~L}$ of SSL/t (S2.0), or (4) $2 \mathrm{~L} / \mathrm{t}$ of CropSaver (BPA; CNH Industrial America LLC, Racine, WI; contained $64.5 \%$ propionic acid and $5 \%$ citric acid as active ingredients). Treatments were applied with a hand sprayer while mixing into the forage mass. Forage from each pile was packed into 7.5$\mathrm{L}$ buckets that served as laboratory silos and sealed with plastic lids with O-ring seals. A single port with rubber tubing leading from the top of each silo was placed into a beaker of water for release of silo gas and permanently sealed after about 2 wk of storage when production of gas ceased. Targeted packing density was approximately $224 \pm 5 \mathrm{~kg}$ of $\mathrm{DM} / \mathrm{m}^{3}$. After filling and sealing, silos were stored at $21 \pm 0.5^{\circ} \mathrm{C}$ for $120 \mathrm{~d}$. Weights of empty and full silos were recorded at filling and at silo openings and used, with the determination of DM content, to calculate DM recovery (DMR) at silo openings.

Fresh, treated forage from each pile from d 0 was sampled and analyzed for DM, NDF, ADF, CP, soluble 
protein $(\mathbf{S P})$, starch, $\mathrm{pH}$, ash, lactic acid bacteria (LAB), yeasts and molds, $\mathrm{NH}_{3}-\mathrm{N}$, and water-soluble carbohydrates (WSC). The DM content of fresh forages and silage samples was determined using a forcedair oven set at $60^{\circ} \mathrm{C}$ for $48 \mathrm{~h}$. After drying, a portion of each sample was ground using a Udy Cyclone sample mill (Udy Corp., Fort Collins, CO) to pass through a 1-mm screen and analyzed for NDF using a heat-stable $\alpha$-amylase via the procedures of Van Soest et al. (1991) and ash (AOAC International, 2002; method 942.05). The concentration of ADF was determined on dried ground samples according to procedures described by Goering and Van Soest (1970) with the modification that the fiber residue from the ADF was recovered on a $1.5-\mu \mathrm{m}$ particle retention 7 -cm Whatman filter in a California Buchner funnel (934-AH, Whatman Inc., Clifton, NJ), instead of a Gooch crucible, to allow for better filtration. Total $\mathrm{N}$ was determined by combustion of the sample (Leco CNS 2000 analyzer, Leco Corp., St. Joseph, MI), and CP was calculated by multiplying total $\mathrm{N}$ by 6.25 . Soluble protein (\% of CP) was determined by the method of Krishnamoorthy et al. (1982). A separate portion of the dried samples was ground to pass through a $3-\mathrm{mm}$ screen and analyzed for starch (Hall, 2009).

Fresh forages and silage samples were mixed with sterile quarter-strength Ringers solution (Oxoid BR0052G, Oxoid, Basingstoke, UK) and homogenized for $1 \mathrm{~min}$ in a Proctor-Silex 57171 blender (Hamilton Beach/Proctor-Silex Inc., Washington, NC). The $\mathrm{pH}$ of the blended mix was measured and filtered through 4 layers of cheesecloth to obtain a water extract. Samples of the extracts were plated on various selective agars using pour-plate methodology within 5 min of blending. The numbers of LAB were determined by pour-plating 10-fold serial dilutions of the water extracts on de Man, Rogosa and Sharpe agar (CM3651, Oxoid). Plates were incubated anaerobically at $32^{\circ} \mathrm{C}$ for 48 to $72 \mathrm{~h}$. Yeasts and molds were also determined by pour-plating 10 -fold serial dilutions of the water extracts on malt extract agar (CM0059, Oxoid). Plates were incubated aerobically at $32^{\circ} \mathrm{C}$ for 48 to $72 \mathrm{~h}$ before enumeration. The fresh water extracts were also filtered through Whatman 54 filter paper and frozen before further analyses. These water extracts from fresh and ensiled samples were processed and analyzed for $\mathrm{NH}_{3}-\mathrm{N}$ (Okuda et al., 1965) and WSC (Nelson, 1944). Silage water extracts were also analyzed for fermentation acids and ethanol via HPLC (Shimazdu, Kyoto, Japan; Muck and Dickerson, 1988).

At silo openings, approximately $2 \pm 0.01 \mathrm{~kg}$ of representative silage from each silo was returned to clean buckets without packing. A thermocouple wire was placed in the geometric center of each silage mass, and temperatures were recorded by a data logger (dataTaker DT85, Thermo Fisher Scientific Australia Pty, Scoresby, VIC, Australia) every $30 \mathrm{~min}$ and averaged for each hour. Silos were covered with 2 layers of cheesecloth and exposed to air in the laboratory (21 \pm $0.5^{\circ} \mathrm{C}$ ). Aerobic stability was determined as the number of hours before the temperature of the silage mass increased $2^{\circ} \mathrm{C}$ above baseline temperature of each silage mass.

\section{Experiment 2}

Whole-plant corn (P1376XR, DuPont Pioneer, Johnston, IA) was harvested at about $38 \%$ DM as described in experiment 1. Five individual replicates were made for (1) untreated control (CON), (2) $2 \mathrm{~L}$ of Safesil/t of fresh forage weight (S2.0), (3) $3 \mathrm{~L}$ of Safesil/t (S3.0), or (4) Silosolve AS (INO; a microbial-based inoculant comprising Enterococcus faecium M74, Lactobacillus plantarum CH6072, and Lactobacillus buchneri LN1819 applied at a final application rate of $150,000 \mathrm{cfu}$ of total LAB/g of fresh forage; Chr. Hansen's Biosystems, Milwaukee, WI). The inoculant was plated on de Man, Rogosa and Sharpe agar before the experiment to verify total numbers of LAB and weighed out on the day of the experiment to yield the targeted application rate. Similar silos used in the previous experiments were used but were filled (packing density of approximately $193 \pm 5 \mathrm{~kg}$ of $\mathrm{DM} / \mathrm{m}^{3}$ ) to allow for a headspace of 20 $\mathrm{mm}$ at the top of each silo. Times and duration of air stress and the length of the ensiling period were as suggested by the Evaluation Scheme for Silage Additives (DLG Commission for Silage Additives, 2006). In addition to gas release ports, silos had two 12-mm holes across from each other at the bottom of each silo and one 12-mm hole on the top lid. Rubber stoppers were used to seal the holes, and a bead of silicone sealant was laid down around the interface of the stopper and hole. Silos were stored at $21 \pm 0.5^{\circ} \mathrm{C}$. After 28 and $42 \mathrm{~d}$ of storage, the stoppers were removed for $24 \mathrm{~h}$ to allow air to infiltrate into the silos. After each aeration, the stoppers were replaced and resealed with silicone sealant. After $49 \mathrm{~d}$ of ensiling, the silos were opened, sampled, and processed as previously described in experiment 1 . Chemical and microbial analyses were as described for experiment 1 with the exception that silages were not analyzed for ADF, NDF, starch, and ash.

\section{Experiment 3}

Whole-plant corn (TMF2H708b, Dow AgroSciences, Indianapolis, IN) was harvested at about $39 \%$ DM as 
described for experiments 1 and 2. Four individually prepared replicated batches of chopped forage were made for each of the following treatments: (1) CON and (2) $2 \mathrm{~L}$ of SSL/t of fresh forage weight (S2.0). Silos (as described in experiment 1) were prepared for each treatment such that 4 replicated silos were opened for each treatment after 5,15 , and $30 \mathrm{~d}$ of storage (at $21 \pm 0.5^{\circ} \mathrm{C}$ ). Fresh forage was analyzed only for DM content, pH, LAB, yeasts, and molds. Silage samples were analyzed only for $\mathrm{DM}, \mathrm{pH}$, fermentation acids, ethanol, LAB, yeasts, DMR, and aerobic stability as previously described.

\section{Experimental Design and Statistical Analysis}

All microbial data were transformed to $\log _{10}$ for presentation and statistical analysis. For experiment 1 , data from d 0 were analyzed separately as a completely randomized design, including the fixed effect of additive treatment in the model. For silages, data were analyzed as a $4 \times 2$ factorial arrangement in a completely randomized design. The model included the fixed effects of harvest DM $(\mathbf{H})$, additive $(\mathbf{A})$, and their interaction $(\mathbf{H} \times \mathbf{A})$. Aerobic stability was determined for $450 \mathrm{~h}$ in experiment 1 ). The aerobic stability was set at that value if silages were still stable at that time. For experiment 2 , the data were analyzed as a completely randomized design. The model included the fixed effect of A. For experiment 3, the data were analyzed as a 2 $\times 3$ factorial arrangement of treatments in a completely randomized design. The model included the fixed effects of day of ensiling $(\mathbf{D}), \mathrm{A}$, and $\mathrm{D} \times \mathrm{A}$. Aerobic stability was determined for $250 \mathrm{~h}$ in experiment 3 . The aerobic stability was set at that value if silages were still stable at that time. For all experiments, data were analyzed using the Fit Model procedure of JMP (SAS Institute Inc., Cary, NC), and differences are reported as significant when $P \leq 0.05$. Means were separated by Tukey's test $(P \leq 0.05)$. All pairwise comparisons are shown only when there were significant interactions. Data are presented as least squares means.

\section{RESULTS}

\section{Experiment 1}

The composition of fresh forages for harvested DM after treatment but before ensiling are shown in Table 1. Low-DM forage was approximately $32 \%$ DM, whereas high-DM forage was about $38 \%$ DM. Plants harvested at the higher DM had lower concentrations of $\mathrm{CP}$ (8.04 vs. $8.45 \%)$, SP (27.30 vs. $30.49 \%)$, ADF (23.78 vs. $25.88 \%$ ), NDF (39.47 vs. $43.03 \%$ ), and ash
(3.41 vs. $4.20 \%$ ) but a higher concentration of starch (28.29 vs. $22.06 \%$ ) compared with low-DM whole-plant corn. We found that the concentration of $\mathrm{NH}_{3}-\mathrm{N}$ and $\mathrm{pH}$ was unaffected by harvest DM, but the numbers of LAB (6.29 vs. $\left.7.04 \log _{10} \mathrm{cfu} / \mathrm{g}\right)$ and yeasts (5.28 vs. 5.74 $\left.\log _{10} \mathrm{cfu} / \mathrm{g}\right)$ were lower in 38 versus $32 \%$ DM plants. There was no main effect of additive for any measurement on fresh forage except for $\mathrm{NH}_{3}-\mathrm{N}$ and $\mathrm{pH}$. The concentration of $\mathrm{NH}_{3}-\mathrm{N}$ was highest for BPA $(0.06 \%)$ compared with all other treatments (0.02-0.04\%), and it was higher for S2.0 than for CON. Treatment with BPA had the lowest initial $\mathrm{pH}$ (5.70) compared with other treatments (range: 5.84-5.88). The concentration of WSC was higher for S2.0 at 38\% DM than at $32 \%$ $\mathrm{DM}$, in contrast to similar values among other treatments $(\mathrm{H} \times \mathrm{A}$ interaction $)$.

The DM and nutritive composition of silages after 120 $\mathrm{d}$ of ensiling are shown in Table 2. Compared with $32 \%$ DM silage, $38 \%$ DM silage had higher concentrations of DM (37.48 vs. $31.83 \%)$ and $\mathrm{NH}_{3}-\mathrm{N}(0.13$ vs. $0.10 \%)$ but lower concentrations of CP (8.69 vs. $8.82 \%)$, SP (51.63 vs. $54.95 \%)$, and WSC (2.17 vs. $3.86 \%$ ). The DMR was higher in $32 \%$ DM (98\%) than in 38\% DM (94\%) silage. The $\mathrm{pH}$ was higher in $38 \% \mathrm{DM}$ (3.76) than in $32 \%$ DM (3.69) silage. Concentrations of lactic acid (4.73 vs. $6.76 \%)$ and acetic acid (1.21 vs. $1.58 \%)$ and numbers of LAB (4.45 vs. $6.14 \log _{10} \mathrm{cfu} / \mathrm{g}$ ) and yeasts (3.53 vs. $3.96 \log _{10} \mathrm{cfu} / \mathrm{g}$ ) were lower in the high- versus low-DM silage. None of the additives affected the concentration of $\mathrm{CP}$ compared with $\mathrm{CON}$, but its concentration was lower in S2.0 (8.55\%) than in BPA (8.94\%). Soluble protein was similar between BPA $(54.2 \%)$ and CON $(54.3 \%)$ when compared with S1.5 (52.08\%) and S2.0 (52.58\%). The concentration of $\mathrm{NH}_{3}-\mathrm{N}$ was also higher in BPA (0.14\%) than in other treatments (range: 0.09$0.11 \%$ ). We found that the additives had no effects on silage $\mathrm{pH}$, concentration of lactic acid, or numbers of LAB and yeasts. Chemical treatments did not affect the concentration of acetic acid in silage compared with CON, but it was greater in BPA $(1.53 \%)$ than in S1.5 (1.27\%). The concentration of propionic acid was greater for BPA when compared with all other treatments at both DM, and its concentration was greater at $32 \% \mathrm{DM}(0.54 \%)$ than at $38 \% \mathrm{DM}(0.38 \% ; \mathrm{H} \times \mathrm{A}$ interaction). Concentrations of ethanol were higher in $32 \%$ DM silage treated with BPA compared with CON at this DM. In addition, treatment with S1.5 and S2.0 was more effective in lowering concentrations of ethanol compared with CON in the $38 \%$ versus $32 \%$ DM silages $(\mathrm{H} \times \mathrm{A}$ interaction $)$. None of the chemical additives affected the DMR compared with CON. However, treatment with S1.5 and S2.0 had higher DMR (98\%) than did BPA (93\%). 
Table 1. Chemical (\% of DM unless stated otherwise) and microbial $\left(\log _{10} \mathrm{cfu} / \mathrm{g}\right.$ of fresh forage weight) composition of fresh whole corn plants harvested at 32 and $38 \% \mathrm{DM}$ and treated with nothing or with an additive containing sodium benzoate, potassium sorbate, and sodium nitrite, ${ }^{1}$ or an additive containing buffered propionic acid and citric acid ${ }^{2}$ before ensiling in experiment $1^{3}$

\begin{tabular}{|c|c|c|c|c|c|c|c|c|c|c|c|c|}
\hline Item $^{4}$ & \multicolumn{4}{|c|}{$32 \% \mathrm{DM}$} & \multicolumn{4}{|c|}{$38 \% \mathrm{DM}$} & SEM & \multicolumn{3}{|c|}{$P$-value ${ }^{5}$} \\
\hline \multicolumn{13}{|c|}{ Chemical composition } \\
\hline $\mathrm{CP}$ & 8.53 & 8.52 & 8.26 & 8.50 & 8.10 & 8.02 & 7.92 & 8.12 & 0.12 & $<0.01$ & 0.24 & 0.92 \\
\hline $\mathrm{SP}, \%$ of $\mathrm{CP}$ & 31.50 & 31.98 & 28.96 & 29.50 & 26.80 & 27.86 & 28.22 & 26.28 & 1.37 & $<0.01$ & 0.17 & 0.32 \\
\hline $\mathrm{NH}_{3}-\mathrm{N}$ & 0.02 & 0.04 & 0.04 & 0.06 & 0.04 & 0.03 & 0.04 & 0.06 & $<0.01$ & 0.43 & $<0.01$ & 0.14 \\
\hline Starch & 23.23 & 20.70 & 22.01 & 22.32 & 27.34 & 28.40 & 26.10 & 31.32 & 2.06 & $<0.01$ & 0.34 & 0.32 \\
\hline WSC & $11.31^{b}$ & $12.08^{\mathrm{b}}$ & $10.81^{b}$ & $10.57^{\mathrm{b}}$ & $12.68^{\mathrm{ab}}$ & $13.70^{\mathrm{ab}}$ & $15.64^{\mathrm{a}}$ & $13.29^{\mathrm{ab}}$ & 0.78 & $<0.01$ & 0.34 & 0.05 \\
\hline Ash & 4.22 & 4.39 & 4.21 & 3.99 & 3.34 & 3.29 & 3.48 & 3.53 & 0.09 & $<0.01$ & 0.84 & 0.06 \\
\hline $\mathrm{pH}$ & 5.91 & 5.88 & 5.97 & 5.88 & 5.78 & 5.88 & 5.73 & 5.52 & 0.03 & 1.00 & 0.04 & 1.00 \\
\hline \multicolumn{13}{|c|}{ Microbial composition } \\
\hline LAB & 7.21 & 6.94 & 7.00 & 6.99 & 6.39 & 6.31 & 6.28 & 6.20 & 0.21 & $<0.01$ & 0.68 & 0.96 \\
\hline Yeasts & 5.63 & 5.78 & 5.78 & 5.76 & 5.08 & 5.17 & 5.33 & 5.55 & 0.19 & $<0.01$ & 0.20 & 0.51 \\
\hline
\end{tabular}

${ }^{\mathrm{a}, \mathrm{b}}$ Means in a row with different superscripts differ $(P \leq 0.05)$.

${ }^{1}$ Safesil (Ab Hanson \& Mohring, Halmstead, Sweden).

${ }^{2}$ CropSaver (CNH Industrial America LLC, Racine, WI).

${ }^{3} \mathrm{CON}=$ untreated; S1.5 = 1.5 L of Safesil/t of fresh forage weight; $\mathrm{S} 2.0=2.0 \mathrm{~L}$ of Safesil $/ \mathrm{t} ; \mathrm{BPA}=2.0 \mathrm{~L}$ of CropSaver $/ \mathrm{t}$.

${ }^{4} \mathrm{SP}=$ soluble protein; WSC $=$ water-soluble carbohydrates; LAB = lactic acid bacteria.

${ }^{5} \mathrm{H}=$ effect of harvest $\mathrm{DM} ; \mathrm{A}=$ effect of additive; $\mathrm{H} \times \mathrm{A}=$ interaction of additive treatment and harvest DM.

The aerobic stability of silages from experiment 1 is shown in Figure 1. Aerobic stability was greater for S1.5 and S2.0 compared with CON and BPA, but the effect was less for S1.5 at 38\% DM compared with the effect at $32 \% \mathrm{DM}(\mathrm{H} \times \mathrm{A}$ interaction $)$.

\section{Experiment 2}

The chemical and microbial composition of fresh forage after treatment but before ensiling is shown in Table 3. The DM content was similar among treatments

Table 2. The DM recovery, chemical composition (\% of DM unless stated otherwise), DM recovery (\%), and microbial composition (log 10 cfu/g of wet weight) of corn silage harvested at 32 or $38 \%$ and treated with an additive containing sodium benzoate, potassium sorbate, and sodium nitrite $^{1}$ or an additive containing buffered propionic acid and citric acid ${ }^{2}$ and ensiled for $120 \mathrm{~d}$ in experiment $1^{3}$

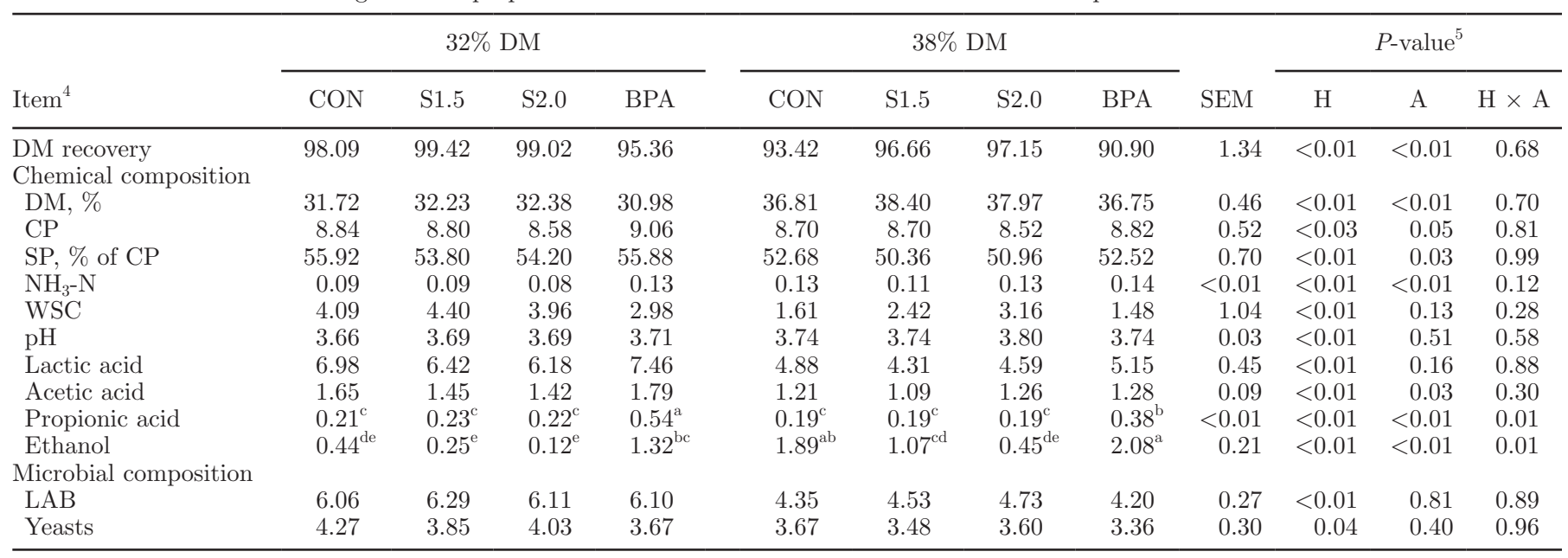

${ }^{\mathrm{a} e}$ Means in rows with unlike superscripts differ $(P \leq 0.05)$.

${ }^{1}$ Safesil (Ab Hanson \& Mohring, Halmstead, Sweden).

${ }^{2}$ CropSaver (CNH Industrial America LLC, Racine, WI).

${ }^{3} \mathrm{CON}=$ untreated; S1.5 $=1.5 \mathrm{~L}$ of Safesil/t of fresh forage weight; S2.0 $=2.0 \mathrm{~L}$ of Safesil $/ \mathrm{t}$; BPA $=2.0 \mathrm{~L}$ of CropSaver $/ \mathrm{t}$.

${ }^{4} \mathrm{SP}=$ soluble protein; WSC $=$ water-soluble carbohydrates; $\mathrm{LAB}=$ lactic acid bacteria.

${ }^{5} \mathrm{H}=$ effect of harvest DM; $\mathrm{A}=$ effect of additive; $\mathrm{H} \times \mathrm{A}=$ interaction of harvest $\mathrm{DM}$ and additive. 
and ranged between 34.37 and $39.99 \%$. Forage $\mathrm{pH}$ was similar between S2.0 (5.91) and S3.0 (5.89), and both were higher compared with INO (5.71). Crude protein ranged from 7.86 to $7.92 \%$ and SP ranged from 29.18 to $31.80 \%$, and both were similar among treatments. The concentrations of $\mathrm{NH}_{3}-\mathrm{N}(0.03-0.04 \%)$, ADF (22.94$23.58 \%)$, NDF (39.72-41.58\%), starch (31.30-33.28\%), and ash (3.49-3.65\%) also did not differ among treatments. The concentration of WSC was lowest for S3.0 (7.69\%), intermediate for S2.0 (8.00\%) and INO (7.91\%), and highest for CON $(9.29 \%)$. Numbers of LAB (7.14-7.38 $\left.\log _{10} \mathrm{cfu} / \mathrm{g}\right)$ and yeasts $\left(5.44-6.18 \log _{10}\right.$ $\mathrm{cfu} / \mathrm{g})$ were similar among treatments.

Data from silages after air stress during storage and $49 \mathrm{~d}$ of ensiling are shown in Table 4. Treatment with the additives (range: 98.96-99.38\%) did not affect the DMR compared with CON (99.20\%). Treatments did not differ in their concentrations of DM (34.37-39.99\%), lactic acid (4.75-4.87\%), or acetic acid (0.98-1.08\%). We did not detect 1,2 propanediol in silage. Inoculation resulted in silage with more LAB $\left(7.13 \log _{10} \mathrm{cfu} / \mathrm{g}\right)$ compared with other treatments (5.88-6.11 $\left.\log _{10} \mathrm{cfu} / \mathrm{g}\right)$. Only treatment with $\mathrm{S} 2.0$ (5.26 $\left.\log _{10} \mathrm{cfu} / \mathrm{g}\right)$ reduced the number of yeasts compared with CON (5.79 $\log _{10}$ $\mathrm{cfu} / \mathrm{g})$. Inoculation $(35 \mathrm{~h})$ did not affect the aerobic stability of silage compared with CON (29 h), but there was a dose-dependent improvement with S2.0 (47 h) and S3.0 (70 h; Figure 2).

\section{Experiment 3}

Fresh whole-plant corn contained 39.39\% DM, had a $\mathrm{pH}$ of 5.87, and contained 7.83 and $6.02 \log _{10}$ cfu of $\mathrm{LAB}$ and yeasts, respectively, for each gram of fresh forage (data not shown). The DMR and chemical and microbial composition of corn silage treated with SSL and ensiled for 5, 15, and $30 \mathrm{~d}$ are shown in Table 5 . Increased time of storage changed the DMR and composition of silages with the exception of ethanol. Dry matter recovery and DM percentage were higher at $5 \mathrm{~d}$ (98.11 and $38.90 \%)$ than at $30 \mathrm{~d}$ (94.64 and $37.57 \%)$, but values for $\mathrm{d} 15$ were not different from the earlier and later time points. Dry matter recovery and DM percentage were not affected by SSL. Silage $\mathrm{pH}$ and the concentration of lactic acid were not different between d $15(3.80$ and $3.98 \%)$ and $d 30(3.78$ and $4.54 \%)$, but they were lower compared with values at $5 \mathrm{~d}$ (3.89 and $2.71 \%$ ). The concentration of acetic acid increased with time in the silo $(0.51 \%$ at $\mathrm{d} 5,0.71 \%$ at $\mathrm{d} 15$, and $0.88 \%$ at $\mathrm{d} 30)$. The number of LAB was highest on d 15 (8.59 $\left.\log _{10} \mathrm{cfu} / \mathrm{g}\right)$ compared with d $5\left(8.01 \log _{10} \mathrm{cfu} / \mathrm{g}\right)$ and d $30\left(8.11 \log _{10} \mathrm{cfu} / \mathrm{g}\right)$. Numbers of yeasts decreased from $6.17 \log _{10} \mathrm{cfu} / \mathrm{g}$ at $\mathrm{d} 5$ to $4.34 \log _{10} \mathrm{cfu} / \mathrm{g}$ at $\mathrm{d}$ 15 and further decreased to $3.10 \log _{10} \mathrm{cfu} / \mathrm{g}$ at $\mathrm{d} 30$. The addition of SSL resulted in a lower $\mathrm{pH}(3.78 \mathrm{vs}$. 3.86 ), a lower concentration of ethanol (1.14 vs. $1.94 \%)$, and lower numbers of yeasts (4.23 vs. $\left.4.84 \log _{10} \mathrm{cfu} / \mathrm{g}\right)$

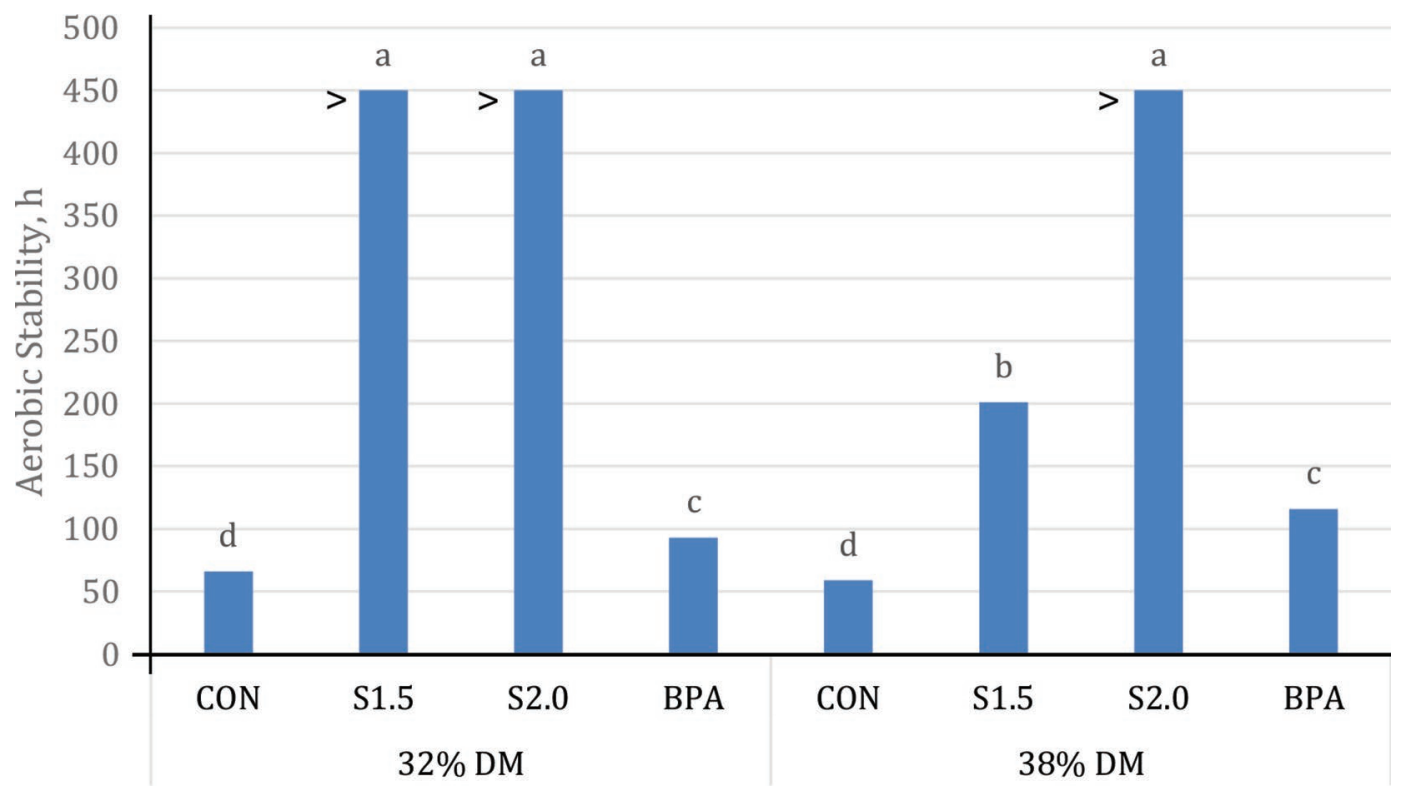

Figure 1. Experiment 1. The aerobic stability of corn silage harvested at 32 and $38 \% \mathrm{DM}$ and treated with no additive (CON) or treated with an additive containing sodium benzoate, potassium sorbate, and sodium nitrite (Safesil, Ab Hanson \& Mohring, Halmstead, Sweden) at 1.5 L (S1.5) or 2 L (S2.0) or an additive containing buffered propionic acid and citric acid (BPA; CropSaver, CNH Industrial America LLC, Racine, WI) at $2.0 \mathrm{~L} / \mathrm{t}$ of fresh forage weight. Aerobic stability was defined as the number of hours before the silage mass increased by $2^{\circ} \mathrm{C}$ when exposed to air at $21 \pm 0.5^{\circ} \mathrm{C}$. $>$ denotes that aerobic stability was greater than $450 \mathrm{~h}$. Bars with different letters $(\mathrm{a}-\mathrm{d})$ differ $(P<0.01)$. Interaction between additive treatment and harvest $\mathrm{DM}, P<0.01 . \mathrm{SEM}=5$. Color version available online. 
Table 3. Chemical (\% of DM unless stated otherwise) and microbial (log cfu/g; fresh weight basis) composition of freshly chopped corn plants after treatment with nothing, an additive containing sodium benzoate, potassium sorbate, and sodium nitrite, ${ }^{1}$ or a microbial inoculant ${ }^{2}$ before ensiling in experiment $2^{3}$

\begin{tabular}{lrrrrrr}
\hline & \multicolumn{7}{c}{ Treatment } \\
\cline { 2 - 4 } Item $^{4}$ & CON & S2.0 & S3.0 & INO & SEM & $P$-value \\
\hline Chemical composition & 34.37 & 39.99 & 38.97 & 38.65 & 1.66 & 0.12 \\
DM, \% & 7.92 & 7.90 & 7.94 & 7.86 & 0.09 & 0.93 \\
CP & 29.18 & 29.22 & 31.80 & 28.68 & 1.02 & 0.17 \\
SP, \% of CP & 0.04 & 0.03 & 0.03 & 0.03 & 0.004 & 0.17 \\
NH & 23.46 & 22.42 & 23.58 & 22.94 & 0.62 & 0.54 \\
ADF & 41.58 & 39.72 & 40.06 & 40.72 & 1.17 & 0.54 \\
NDF & 31.72 & 33.28 & 31.30 & 32.14 & 1.23 & 0.70 \\
Starch & $9.29^{\mathrm{a}}$ & $8.00^{\mathrm{b}}$ & $7.69^{\mathrm{c}}$ & $7.91^{\mathrm{b}}$ & 0.03 & $<0.01$ \\
WSC & 3.65 & 3.49 & 3.57 & 3.52 & 0.10 & 0.74 \\
Ash & 5.80 & 5.91 & 5.89 & 5.71 & 0.73 & 0.42 \\
pH & & & & & & \\
Microbial composition & 7.38 & 7.20 & 7.14 & 7.25 & 0.09 & 0.34 \\
LAB & 5.44 & 5.82 & 5.75 & 6.18 & 0.21 & 0.13 \\
Yeasts & &
\end{tabular}

${ }^{\mathrm{a}-\mathrm{c}}$ Means in rows with different superscripts differ $(P<0.05)$.

${ }^{1}$ Safesil (Ab Hanson \& Mohring, Halmstead, Sweden).

${ }^{2}$ Silosolve AS (a microbial-based inoculant comprising Enterococcus faecium M74, Lactobacillus plantarum CH6072, and Lactobacillus buchneri LN1819 applied at a final application rate of 150,000 cfu of total LAB/g of fresh forage; Chr. Hansen's Biosystems, Milwaukee, WI).

${ }^{3} \mathrm{CON}=$ untreated; $\mathrm{S} 2.0=2 \mathrm{~L}$ of Safesil/t of fresh forage weight; $\mathrm{S} 3.0=3.0 \mathrm{~L}$ of Safesil/t; INO = Silosolve AS.

${ }^{4} \mathrm{SP}=$ soluble protein; WSC $=$ water-soluble carbohydrates; LAB = lactic acid bacteria

compared with untreated silage. The addition of SSL did not affect the concentrations of lactic and acetic acids and the numbers of LAB. Treatment with SSL improved the aerobic stability of corn silage after each day of ensiling, but the effect was greater at 15 and 30 $\mathrm{d}$ than at $5 \mathrm{~d}(\mathrm{D} \times \mathrm{A}$ interaction; Figure 3$)$.

Table 4. The DM recovery, chemical composition (\% of DM unless stated otherwise), DM recovery (\%), and microbial composition (log cfu/g; fresh weight basis) of corn silage treated with nothing, an additive containing sodium benzoate, potassium sorbate, and sodium nitrite, ${ }^{1}$ or a microbial inoculant ${ }^{2}$ and subjected to air stresses for $24 \mathrm{~h}$ at 28 and $42 \mathrm{~d}$ and ensiled for $49 \mathrm{~d}$ in experiment $2^{3}$

\begin{tabular}{|c|c|c|c|c|c|c|}
\hline \multirow[b]{2}{*}{ Item $^{4}$} & \multicolumn{4}{|c|}{ Treatment } & \multirow[b]{2}{*}{ SEM } & \multirow[b]{2}{*}{$P$-value } \\
\hline & $\mathrm{CON}$ & S2.0 & S3.0 & INO & & \\
\hline DM recovery & $99.20^{\mathrm{ab}}$ & $99.26^{\mathrm{ab}}$ & $99.38^{\mathrm{a}}$ & $98.96^{\mathrm{b}}$ & 0.01 & 0.04 \\
\hline \multicolumn{7}{|l|}{ Chemical composition } \\
\hline DM, \% & $38.52^{\mathrm{ab}}$ & $38.90^{\mathrm{a}}$ & $37.19^{\mathrm{bc}}$ & $36.88^{\mathrm{c}}$ & 0.79 & $<0.01$ \\
\hline $\mathrm{CP}$ & 7.72 & 7.52 & 7.72 & 7.72 & 0.18 & 0.23 \\
\hline $\mathrm{SP}, \%$ of $\mathrm{CP}$ & $43.90^{\mathrm{b}}$ & $44.00^{\mathrm{b}}$ & $47.04^{\mathrm{a}}$ & $42.54^{\mathrm{b}}$ & 1.52 & $<0.01$ \\
\hline $\mathrm{NH}_{3}-\mathrm{N}$ & $0.05^{\mathrm{b}}$ & $0.05^{\mathrm{b}}$ & $0.05^{\mathrm{b}}$ & $0.07^{\mathrm{a}}$ & 0.007 & $<0.01$ \\
\hline WSC & $1.15^{\mathrm{b}}$ & $1.79^{\mathrm{a}}$ & $2.07^{\mathrm{a}}$ & $1.20^{\mathrm{b}}$ & 0.22 & $<0.01$ \\
\hline $\mathrm{pH}$ & $3.60^{\mathrm{b}}$ & $3.63^{\mathrm{b}}$ & $3.71^{\mathrm{a}}$ & $3.74^{\mathrm{a}}$ & 0.04 & $<0.01$ \\
\hline Lactic acid, \% & 4.70 & 5.04 & 4.75 & 4.87 & 0.63 & 0.84 \\
\hline Acetic acid, \% & 1.05 & 1.08 & 0.98 & 1.06 & 0.14 & 0.66 \\
\hline Ethanol, \% & $0.76^{\mathrm{a}}$ & $0.41^{\mathrm{b}}$ & $0.35^{\mathrm{b}}$ & $0.94^{\mathrm{a}}$ & 0.15 & $<0.01$ \\
\hline \multicolumn{7}{|l|}{ Microbial composition } \\
\hline LAB & $6.11^{\mathrm{b}}$ & $5.96^{\mathrm{b}}$ & $5.88^{\mathrm{b}}$ & $7.13^{\mathrm{a}}$ & 0.32 & $<0.01$ \\
\hline Yeasts & $5.79^{\mathrm{a}}$ & $5.26^{\mathrm{b}}$ & $5.70^{\mathrm{ab}}$ & $5.86^{\mathrm{a}}$ & 0.34 & 0.05 \\
\hline
\end{tabular}

${ }^{\mathrm{a}-\mathrm{c}}$ Means in a row with different superscripts differ $(P \leq 0.05)$.

${ }^{1}$ Safesil (Ab Hanson \& Mohring, Halmstead, Sweden).

${ }^{2}$ Silosolve AS (a microbial-based inoculant comprising Enterococcus faecium M74, Lactobacillus plantarum CH6072, and Lactobacillus buchneri LN1819 applied at a final application rate of 150,000 cfu of total LAB/g of fresh forage; Chr. Hansen's Biosystems, Milwaukee, WI).

${ }^{3} \mathrm{CON}=$ untreated; $\mathrm{S} 2.0=2 \mathrm{~L}$ of Safesil/t of fresh forage weight; $\mathrm{S} 3.0=3.0 \mathrm{~L}$ of Safesil/t; INO = Silosolve AS. ${ }^{4} \mathrm{SP}=$ soluble protein WSC $=$ water-soluble carbohydrates; LAB = lactic acid bacteria. 
Table 5. Dry matter recovery (\%), DM (\%), pH, fermentation end products (\% of DM), lactic acid bacteria (LAB), and yeasts (log 10 cfu/g of

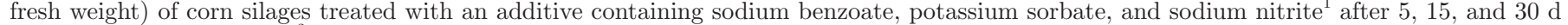
of ensiling in experiment $3^{2}$

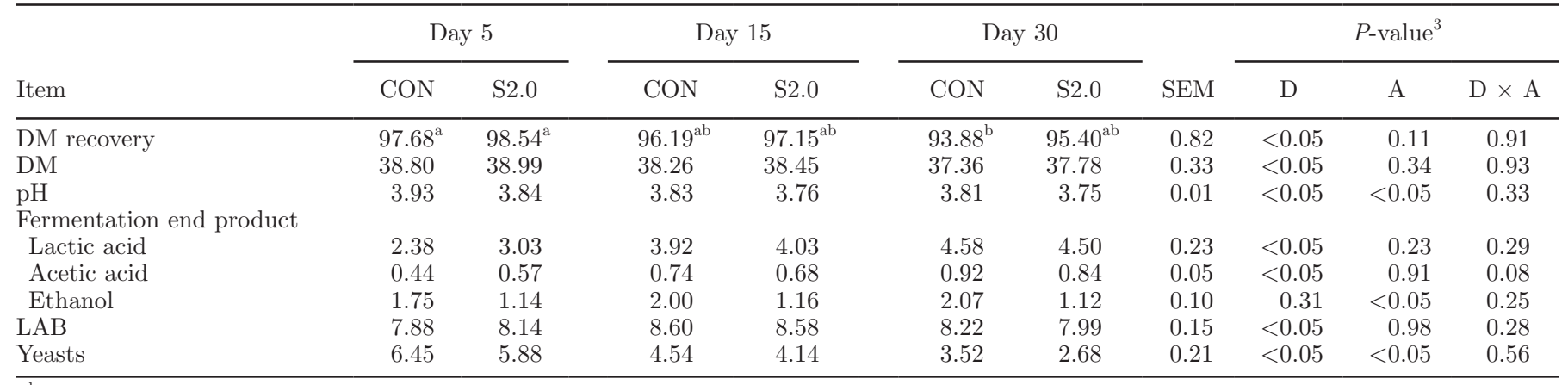

$\overline{\mathrm{a}, \mathrm{b}}$ Means in a row with different superscripts differ $(P \leq 0.05)$.

${ }^{1}$ Safesil (Ab Hanson \& Mohring, Halmstead, Sweden).

${ }^{2} \mathrm{CON}=$ untreated silage; $\mathrm{S} 2.0=$ Safesil added at $2 \mathrm{~L} / \mathrm{t}$ of fresh forage weight.

${ }^{3} \mathrm{D}=$ effect of day of ensiling; $\mathrm{A}=$ effect of additive; $\mathrm{D} \times \mathrm{A}=$ interaction of day of ensiling and additive.

\section{DISCUSSION}

Silages in all experiments ensiled well as indicated by low $\mathrm{pH}$, higher concentrations of lactic than acetic acid, and a lack of butyric acid. In experiment 1, we found changes in nutrient composition and fermentation end products that were similar to findings from numerous past studies (Hu et al., 2009; Der Bedrosian et al., 2012). For example, increasing DM at harvest reduced the concentrations of $\mathrm{CP}, \mathrm{ADF}$, and NDF but increased

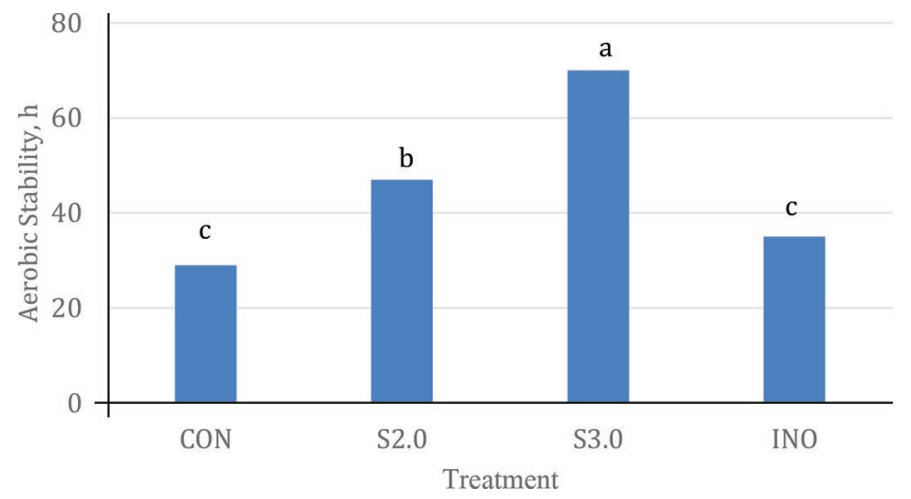

Figure 2. Experiment 2. The aerobic stability of corn silage treated with no additive $(\mathrm{CON})$ or treated with an additive containing sodium benzoate, potassium sorbate, and sodium nitrite (Safesil, Ab Hanson \& Mohring, Halmstead, Sweden) at $2 \mathrm{~L}$ (S2.0) or $3 \mathrm{~L} / \mathrm{t}$ of fresh forage weight (S3.0) or a microbial-based inoculant (INO; Silosolve AS, Chr. Hansen's Biosystems, Milwaukee, WI) comprising Enterococcus faecium M74, Lactobacillus plantarum CH6072, and Lactobacillus buchneri LN1819 and applied at a final application rate of 150,000 cfu of total lactic acid bacteria/g of fresh forage). Silages in silos were air-stressed for $24 \mathrm{~h}$ at 28 and $42 \mathrm{~d}$ of storage and then loosely exposed to air after $49 \mathrm{~d}$ of ensiling for the determination of aerobic stability, defined as the number of hours before the silage mass increased by $2^{\circ} \mathrm{C}$ after exposure to air at $21 \pm 0.5^{\circ} \mathrm{C}$. Bars with different letters $(\mathrm{a}-\mathrm{c})$ differ $(P$ $<0.01)$. SEM $=4$. Color version available online. the concentration of starch. Increasing DM at harvest also resulted in silages with lower concentrations of SP and lactic acid but higher $\mathrm{pH}$. In experiment 3 , we found that changes in fermentation end products with time of ensiling were also as expected. These changes included an increase in acid production, decrease in $\mathrm{pH}$, and increase in numbers of $\mathrm{LAB}$ with progressive time in the silo. As changes in composition of silage due to harvest maturity and time of ensiling were normal, we focused the remainder of our discussion on results specific to treatments with the additives on silage fermentation and aerobic stability.

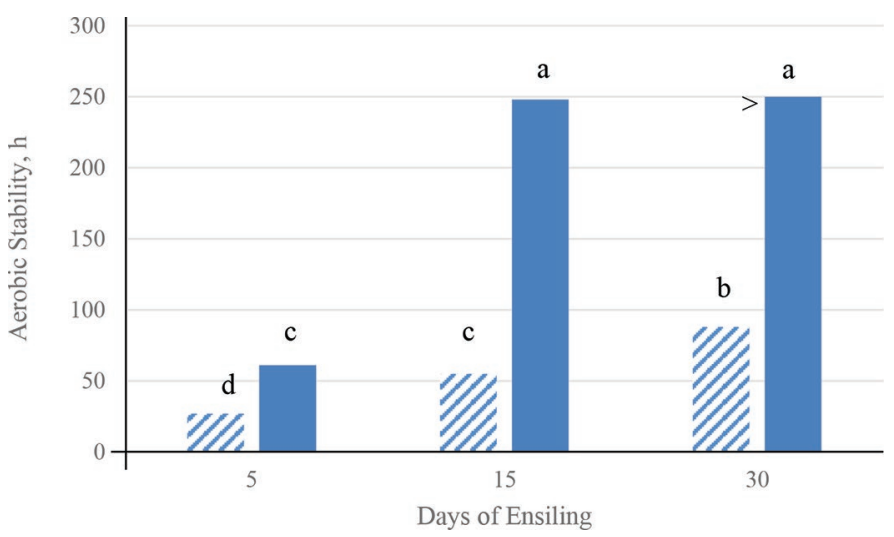

Figure 3. Experiment 3. The aerobic stability of corn silage treated with no additive (striped bars) or treated with an additive containing sodium benzoate, potassium sorbate, and sodium nitrite (solid bars; Safesil, Ab Hanson \& Mohring, Halmstead, Sweden) at $2 \mathrm{~L} / \mathrm{t}$ of fresh forage weight. Aerobic stability was defined as the number of hours before the silage mass increased by $2^{\circ} \mathrm{C}$ when exposed to air at $21 \pm$ $0.5^{\circ} \mathrm{C}$. > denotes that aerobic stability was greater than $250 \mathrm{~h}$. Bars with different letters $(\mathrm{a}-\mathrm{d})$ differ $(P<0.05)$. Interaction between additive treatment and harvest DM, $P<0.05 . \mathrm{SEM}=6$. Color version available online. 
Potassium sorbate (Teller et al., 2012; Bernardes et al., 2015; Hafner et al., 2015) and sodium benzoate (Kleinschmit et al., 2005; Bernardes et al., 2015) by themselves have decreased the numbers of yeasts in silages. Combining organic acids to inhibit fungi has recently become popular (Knicky and Spörndly, 2011; Nadeau et al., 2012; Weiss et al., 2016) because together these acids have the potential to act on multiple species and may interfere with different metabolic pathways within the same species, thereby increasing the overall inhibitory effect (Stanojevic et al., 2009; Dai et al., 2010). The efficacy of organic acids as antifungal treatments is dependent not only on the mixture of acids but also on the $\mathrm{pH}$ they are placed in because they are most effective when the $\mathrm{pH}$ is lower than their $\mathrm{p} K_{\mathrm{a}}$ (Lambert and Stratford, 1999; Ullah et al., 2012). For these acids, they are only $50 \%$ undissociated when the $\mathrm{pH}$ of the system is equal to their $\mathrm{p} K_{\mathrm{a}}$, and it is this form that has antifungal attributes. Opportunistically, whole-plant corn has a relatively low buffering capacity (e.g., compared with alfalfa), allowing its $\mathrm{pH}$ to decrease quickly during ensiling. In experiment 3 , the $\mathrm{pH}$ of fresh material was 5.67 , but after $5 \mathrm{~d}$ it had dropped below 3.9. We found that, overall, treatment with SSL had no effect on the concentrations of lactic and acetic acids across all experiments, and this was supported by a lack of effect on numbers of LAB. Effects of SSL on concentrations of WSC, $\mathrm{NH}_{3}-\mathrm{N}$, and SP varied among studies, and we found no consistent effect due to addition of this additive on these measurements. In high-moisture corn (HMC), da Silva et al. (2015) reported that high levels of SSL reduced $\mathrm{NH}_{3}-\mathrm{N}$ and $\mathrm{SP}$ when compared with untreated HMC or HMC treated with a low level of SSL. Knicky and Spörndly (2011) also found that SSL reduced $\mathrm{NH}_{3}-\mathrm{N}$ in difficult-to-ensile crops but not in easy-to-ensile crops. In their study, that effect could be explained by the inhibitory effects of sodium nitrite (from SSL) on clostridia (Bowen et al., 1974). However, in corn silage and HMC, clostridia are not competitive, and thus the mechanism for reduced proteolysis in these crops by SSL is less clear. In experiment 1 of our study, the high concentration of $\mathrm{NH}_{3}-\mathrm{N}$ in BPA was most likely a direct result of the additive as ammonium hydroxide is a component of the BPA formulation, buffering propionic acid and making it safer to handle.

The most consistent effect from the addition of SSL on fermentation end products in the current experiments was a reduction in the concentration of ethanol compared with untreated corn silages. Knicky and Spörndly $(2011,2015)$ also reported that using SSL decreased the concentration of ethanol in a variety of crops in Europe. da Silva et al. (2015) reported similar effects of SSL on HMC in North America. In contrast, neither BPA nor INO reduced the concentration of ethanol when compared with untreated silage. Lower concentrations of ethanol in silages treated directly with potassium sorbate (Teller et al., 2012) or sodium benzoate (Kleinschmit et al., 2005) are best explained by effects on yeasts, although enterobacteria and heterolactic acid bacteria also produce ethanol (Pahlow et al., 2003). However, in the current experiments, SSL had somewhat varying statistical effects on the numbers of yeasts in silage. Yeasts were only numerically lower in silages treated with SSL and BPA in experiment 1. In our second experiment, yeasts were lower in S2.0 than in CON, but S3.0 was not different from S.20 and CON. Treatment with SSL in experiment 3 reduced numbers of yeasts at all silo openings.

Treatment with SSL also consistently improved the aerobic stability of corn silage in all of the current experiments. Impressively, treatment with SSL resulted in silages that were stable for the 450-h period of monitoring in experiment 1 and for the 250-h period in experiment 3. Knicky and Spörndly $(2011,2015)$ reported an improvement in aerobic stability in a variety of crops in Europe, and da Silva et al. (2015) showed that it did the same in HMC in North America. We found that treatment with S1.5 and S2.0 resulted in marked improvements in aerobic stability compared with CON and BPA in experiment 1 . However, the effect was not as great for the $1.5 \mathrm{~L} / \mathrm{t}$ addition at $38 \% \mathrm{DM}$, suggesting that this drier material presented a greater challenge, probably because of greater porosity and lower production of acetic acid in the higher DM silage. In experiment 2, we subjected silages to air stress during storage (DLG Commission for Silage Additives, 2006) because on-farm conditions seldom have the ability to maintain silos in true anaerobic conditions. Silages can be exposed to air during storage due to various reasons. For example, poor packing densities, slow feedout rates, poor covering techniques, and damage to integrity of plastics from animals or environmental challenges (e.g., damage from hail) can cause egress of air into a silage mass. No one laboratory method of invoking air stress will characterize every potential airstress challenge that silages may face, but this is true of other variables, such as storage temperatures and packing densities, that vary tremendously in the field. For example, Jonsson and Pahlow (1984) air-stressed silos continuously with a $\mathrm{CO}_{2}$-air mixture that resulted in $220 \mathrm{mg}$ of $\mathrm{O}_{2} / \mathrm{kg}$ of DM per day, but others (Herrmann et al., 2015; Knicky and Spörndly, 2015) have used air stress methods similar to that in the current study. In addition, because SSL is marketed in Europe, we chose to follow an air-stress protocol established 
by a European regulatory body (DLG Commission for Silage Additives, 2006). Treatment with SSL in experiment 2 resulted in dose-dependent but modest improvements in aerobic stability compared with that found in experiments 1 and 3. Air stress during storage was most likely responsible for the relatively lowered effect. Addition of BPA also improved aerobic stability of silages at $32 \%$ (increase of $27 \mathrm{~h}$ ) and $38 \%$ (increase of $57 \mathrm{~h}$ ) DM in experiment 1, but the effects were markedly less substantial compared with SSL (increases of hundreds of hours). In experiment 3, SSL improved aerobic stability after relatively short times of ensiling, but the magnitude of the effect was greater after 15 and $30 \mathrm{~d}$ of ensiling than after $5 \mathrm{~d}$. Early improvements in aerobic stability may be useful for dairy farmers who are faced with feeding chopped corn plants after only short periods of ensiling but without treatment would be faced with feeding unstable silage.

Treatment with the microbial inoculant containing L. buchneri did not improve the aerobic stability of corn silage. We believe that this finding was due to the relatively short ensiling period of $49 \mathrm{~d}$, although, unexplainably, INO had the highest numbers of total LAB of all treatments. We also cannot explain why INO was higher in $\mathrm{NH}_{3}-\mathrm{N}$ than $\mathrm{CON}$. Treatment with INO also resulted in silage with a higher $\mathrm{pH}$ than $\mathrm{CON}$, but the difference was small and not biologically significant. Lactobacillus buchneri is slow growing compared with most LAB in silage (Schmidt et al., 2009) and takes about 45 to $60 \mathrm{~d}$ before it can produce sufficient quantities of acetic acid to affect fungal growth (Kleinschmit and Kung, 2006). In support of this thesis, we could not detect 1,2 propanediol, which is normally produced when lactic acid is converted to acetic acid by $L$. buchneri. Additionally, treatment with L. buchneri has not been successful in sugarcane silage, suggesting that it is not competitive in some ensiling environments (Daniel et al., 2015).

In the current set of experiments, the correlation between yeasts and aerobic stability was not as strong $\left(\mathrm{y}=-71.237 \mathrm{x}+470.9, \mathrm{R}^{2}=0.27, P<0.03\right.$; data not shown) as that reported by Kung et al. (1998; y = $\left.-45.7 \mathrm{x}+315.4, \mathrm{R}^{2}=0.79\right)$. Using these equations, the aerobic stability of the current experiments was projected to be 0 when numbers of yeasts were about 6.61 $\log _{10} \mathrm{cfu} / \mathrm{g}$ compared with $6.9 \log _{10} \mathrm{cfu} / \mathrm{g}$ in the experiments by Kung et al. (1998). However, aerobic stability has not always been well correlated with numbers of yeasts in some studies. For example, da Silva et al. (2015) found that compared with untreated HMC, the addition of SSL markedly improved aerobic stability, but there were no statistical differences in numbers of total yeasts among treatments. Similarly, Kleinschmit et al. (2005) reported only small numerical reductions in numbers of yeasts in corn silages treated with sodium benzoate or potassium sorbate and EDTA, but the resulting silages were markedly more stable when exposed to air than was untreated control silage. The reasons for weak correlations between numbers of total yeasts in silages and aerobic stability in some experiments may be due to several factors. First, enumeration of yeasts with malt extract agar does not differentiate between yeasts that are capable of assimilating lactic acid compared with those that are not, and it is these former organisms that initiate aerobic spoilage in many silages. Short-chain organic acids are also usually fungistatic and not always fungicidal (Lacey et al., 1991; Ullah et al., 2012), and effects are dependent on concentration and the length of time of exposure (Neal et al., 1965). This later suggestion was supported by the fact that addition of SSL reduced the numbers of yeasts by $9 \%$ on d 5 and $24 \%$ on d 30 compared with untreated silage in experiment 3.

What remains unexplained in our set of experiments is why some silages treated with SSL were stable for such long periods of time (e.g., $>450 \mathrm{~h}$ in experiment 1). Teller et al. (2012) reported that corn silage treated with potassium sorbate at $0.1 \%$ of fresh forage weight markedly reduced the numbers of yeasts to levels below $1 \log _{10} \mathrm{cfu} / \mathrm{g}$ compared with untreated silages with 4.41 to $5.26 \log _{10} \mathrm{cfu}$ of yeasts/g, but treated silages were stable for only 141 to $168 \mathrm{~h}$ compared with untreated silages (34-36 h). The differences in results between the current experiments and that of Teller et al. (2012) reinforces the fact that other populations of microbes are involved in aerobic deterioration. For example, Acetobacter have been implicated in initiating aerobic instability in corn silage (Spoelstra et al., 1988). We speculate that these organisms may have been responsible for treated silages that were exposed to air during storage in experiment 2 to have more moderate improvements in stability compared with the findings in experiment 1.

\section{CONCLUSIONS}

We found that SSL increased the aerobic stability of corn silage under North American conditions. Treatment with SSL improved aerobic stability in corn silage ranging from 32 to $39 \% \mathrm{DM}$, and it was more effective than an additive containing buffered propionic acid and citric acid. Aerobic stability was also improved in corn silage treated with SSL and subjected to air stress during storage, whereas treatment with L. buchneri was ineffective, most likely because of the short period of ensiling. Improvements in aerobic stability from SSL 
were also observed as early as 5 and $15 \mathrm{~d}$ after ensiling, which may be important to dairy producers who feed corn silage after very short periods of ensiling and are concerned about aerobic stability.

\section{ACKNOWLEDGMENTS}

These experiments were partially funded by Salinity Agro, AB Hanson \& Mohring, Halmstead, Sweden. The authors thank the staff at the University of Delaware Farm (Newark) for growing and harvesting the crops.

\section{REFERENCES}

AOAC International. 2002. Official Methods of Analysis. 17th ed. AOAC International, Arlington, VA.

Bernardes, T. F., I. L. De Oliveira, M. A. S. Lara, D. R. Cassgrande, C. L. S. Avila, and O. G. Pereira. 2015. Effects of potassium sorbate and sodium benzoate at two application rates on fermentation and aerobic stability of maize silage. Grass Forage Sci. 70:491-498.

Bowen, V. G., J. G. Cerveny, and R. H. Deibel. 1974. Effect of sodium ascorbate and sodium nitrite on toxin formation of Clostridium botulinum in wieners. Appl. Microbiol. 27:605-606.

Britt, D. G., J. T. Huber, and A. L. Rogers. 1975. Fungal growth and acid production during fermentation and refermentation of organic acid treated corn silages. J. Dairy Sci. 58:532-539.

da Silva, T. C., M. L. Smith, A. M. Barnard, and L. Kung Jr.. 2015. The effect of a chemical additive on the fermentation and aerobic stability of high-moisture corn. J. Dairy Sci. 98:8904-8912.

Dai, Y., M. D. Normand, J. Weiss, and M. Peleg. 2010. Modeling the efficacy of triplet antimicrobial combinations: Yeast suppression by lauric arginate, cinnamic acid, and sodium benzoate or potassium sorbate as a case study. J. Food Prot. 73:515-523.

Daniel, J. L. P., M. Checolli, J. Zwielehner, D. Junges, J. Fernandes, and L. G. Nussio. 2015. The effects of Lactobacillus kefiri and L. brevis on the fermentation and aerobic stability of sugarcane silage. Anim. Feed Sci. Technol. 205:69-74.

Deak, T. 2008. Handbook of Food Spoilage Yeasts. 2nd ed. CRC Press, Boca Raton, FL.

Der Bedrosian, M. C., K. E. Nestor, and L. Kung Jr.. 2012. The effects of hybrid, maturity, and length of storage on the composition and nutritive value of corn silage. J. Dairy Sci. 95:5115-5126.

DLG Commission for Silage Additives. 2006. DLG guidelines for the test of silage additives for approval of DLG quality labels. DLG Commission for Silage Additives, Frankfurt, Germany.

Goering, H. K., and P. J. Van Soest. 1970. Forage fiber analyses (apparatus, reagents, procedures, and some applications). Agric. Handbook No. 379. USDA Agricultural Research Service, Washington, DC.

Hafner, S., M. C. Windle, C. Merrill, M. L. Smith, R. B. Franco, and L. Kung Jr.. 2015. Effects of potassium sorbate and Lactobacillus plantarum MTD1 on production of ethanol and other volatile organic compounds in corn silage. Anim. Feed Sci. Technol. 208:79-85.

Hall, M. B. 2009. Analysis of starch, including maltooligosaccharides, in animal feeds: Comparison of methods and a recommended method for AOAC collaborative study. J. AOAC Int. 92:42-49.

Herrmann, C., C. Idler, and M. Heiermann. 2015. Improving aerobic stability and biogas production of maize silage using silage additives. Bioresour. Technol. 197:393-403.

Hoffman, P. C., and S. M. Ocker. 1997. Quantification of milk yield losses associated with feeding aerobically unstable high moisture corn. J. Dairy Sci. 80(Suppl. 1):234. (Abstr.)

Hu, W., R. J. Schmidt, E. E. McDonell, C. M. Klingerman, and L. Kung Jr.. 2009. The effect of Lactobacillus buchneri 40788 or L. plantarum MTD-1 on the fermentation and aerobic stability of corn silages ensiled at two dry matter contents. J. Dairy Sci. 92:3907-3914.

Jonsson, A., and G. Pahlow. 1984. Systematic classification and biochemical characterization of yeasts growing in grass silage inoculated with Lactobacillus cultures. Anim. Res. Dev. 20:7-22.

Kleinschmit, D. H., and L. Kung Jr. 2006. The effects of Lactobacillus buchneri 40788 and Pediococcus pentosaceus R1094 on the fermentation of corn silage during various stages of ensiling. J. Dairy Sci. 89:3999-4004.

Kleinschmit, D. H., R. J. Schmidt, and L. Kung Jr. 2005. The effects of various antifungal additives on the fermentation and aerobic stability of corn silage. J. Dairy Sci. 88:2130-2139.

Knicky, M., and R. Spörndly. 2011. The ensiling capability of a mixture of sodium benzoate, potassium sorbate, and sodium nitrite. J. Dairy Sci. 94:824-831.

Knicky, M., and R. Spörndly. 2015. Use of a mixture of sodium nitrite, sodium benzoate and potassium sorbate in aerobically challenged silages. J. Dairy Sci. 98:5729-5734.

Krishnamoorthy, U., T. V. Muscato, C. J. Sniffen, and P. J. Van Soest. 1982. Borate phosphate procedure as detailed in nitrogen fractions in selected feedstuffs. J. Dairy Sci. 65:217-225.

Kung, L. Jr., J. R. Robinson, N. K. Ranjit, J. H. Chen, and C. M. Golt. 2000. Microbial populations, fermentation end products, and aerobic stability of corn silage treated with ammonia or a propionic acid-based preservative. J. Dairy Sci. 83:1479-1486.

Kung, L. Jr., A. C. Sheperd, A. M. Smagala, K. M. Endres, C. A. Bessett, N. K. Ranjit, and J. L. Glancey. 1998. The effect of propionic acid-based preservatives on the fermentation and aerobic stability of corn silage and a total mixed ration. J. Dairy Sci. 81:1322-1330.

Kung, L., Jr., M. R. Stokes, and C. J. Lin. 2003. Silage additives. Pages 305-360 in Silage Science and Technology. D. R. Buxton, R. E. Muck, and J. H. Harrison, ed. American Society of Agronomy, Madison, WI.

Lacey, J., N. Ramakrishna, A. Hamer, N. Magan, and I. C. Marfleet. 1991. Grain fungi. Pages 121-177 in Handbook of Applied Mycology. Vol. 3. Foods and Feeds. D. K. Arora, K. G. Mukerji, and E. H. Marth, ed. Marcel Decker Inc., New York, NY.

Lambert, R. J., and M. Stratford. 1999. Weak-acid preservatives: Modelling microbial inhibition and response. J. Appl. Microbiol. 86:157-164.

Muck, R. E., and J. T. Dickerson. 1988. Storage temperature effects on proteolysis in alfalfa silage. Trans. ASAE 31:1005-1009.

Muck, R. E., and R. L. Huhnke. 1995. Oxygen infiltration from horizontal silo unloading practices. Trans. ASAE 38:23-31.

Nadeau, E., A. Arnesson, and H. Auerbach. 2012. Effects of additive and particle size on fermentation characteristics and aerobic stability of grass silage. Pages $380-381$ in Proc. XVI International Silage Conference, Hameenlinna, Finland. K. Kuoppala, M. Rinne, and A. Vanhatalo, ed. MTT Agrifood Research Finland and University of Helsinki, Finland.

Neal, A. L., J. O. Weinstock, and J. O. Lampen. 1965. Mechanisms of fatty acid toxicity of yeasts. J. Bacteriol. 90:126-131.

Nelson, N. 1944. A photometric adaptation of the Somogyi method for the determination of glucose. J. Biol. Chem. 153:375-380.

Okuda, H., S. Fujii, and Y. Kawashima. 1965. A colorimetric determination of blood ammonia. Tokushima J. Exp. Med. 12:11-23.

Pahlow, G., R. E. Muck, F. Driehuis, S. J. W. H. Oude-Elferink, and S, F. Spoelstra. 2003. Microbiology of ensiling. Pages 31-94 in Silage Science and Technology. D. R. Buxton, R. E. Muck, and J. H. Harrison, ed. American Society of Agronomy, Madison, WI

Pitt, R. E., and R. E. Muck. 1993. A diffusion model of aerobic deterioration at the exposed face of bunker silos. J. Agric. Eng. Res. 55:11-26.

Queiroz, O. C. M., K. G. Arriola, J. L. P. Daniel, and A. T. Adesogan. 2013. Effects of 8 chemical and bacterial additives on the quality of corn silage. J. Dairy Sci. 96:5836-5843.

Schmidt, R. J., W. Hu, J. A. Mills, and L. Kung Jr. 2009. The development of lactic acid bacteria and Lactobacillus buchneri and their effects on the fermentation of alfalfa silage. J. Dairy Sci. 92:5005-5010. 
Seppala, A., M. M. Heikkila, and M. Rinne. 2016. Effects of additives on the fermentation and aerobic stability of grass silages and total mixed rations. Grass Forage Sci. 71:458-471.

Spoelstra, S. F., M. G. Courtin, and J. A. C. Van Beers. 1988. Acetic acid bacteria can initiate aerobic deterioration of whole crop maize silage. J. Agric. Sci. 111:127-132.

Stanojevic, D., L. Comic, O. Stefanovic, and L. Solujic-Sukdolak. 2009. Antimicrobial effects of sodium benzoate, sodium nitrite and potassium sorbate and their synergistic action in vitro. Bulg. J. Agric. Sci. 15:307-311.

Teller, R. S., R. J. Schmidt, L. W. Whitlow, and L. Kung Jr.. 2012 Effect of physical damage to ears of corn before harvest and treatment with various additives on the concentration of mycotoxins, silage fermentation, and aerobic stability of corn silage. J. Dairy Sci. 95:1428-1436.
Ullah, A., R. Orij, S. Brul, and G. J. Smits. 2012. Quantitative analysis of the modes of growth inhibition by weak organic acids in Saccharomyces cerevisiae. Appl. Environ. Microbiol. 78:8377-8387.

Van Soest, P. J., J. B. Robertson, and B. A. Lewis. 1991. Methods for dietary fiber, neutral detergent fiber, and nonstarch polysaccharides in relation to animal nutrition. J. Dairy Sci. 74:3583-3597.

Weiss, K., B. Kroschewski, and H. Auerbach. 2016. Effects of air exposure, temperature and additives on fermentation characteristics, yeast count, aerobic stability and volatile organic compounds in corn silage. J. Dairy Sci. 99:8053-8069.

Windle, M. C., and L. Kung Jr. 2013. The effect of a feed additive on the feeding value of a silage-based TMR exposed to air. J. Dairy Sci. 91(E-Suppl. 1):16. (Abstr.)

Woolford, M. K. 1990. The detrimental effects of air on silage. J. Appl. Bacteriol. 68:101-116. 